\title{
Ethnic Malay Knowledge System against Reproductive Health of Pregnant Women in Paluh Sibaji Pantai Labu Deli Serdang
}

\author{
Desyanti Girsang ${ }^{1 *}$, Ratih Baiduri ${ }^{2}$, Hidayat $^{3}$ \\ \{desyantigirsanglehu@gmail.com ${ }^{1}$ \} \\ Department of Anthropology Education, State University of Medan, Medan, Indonesia ${ }^{123}$
}

\begin{abstract}
This paper seeks to explore the system of local knowledge of ethnic Malay communities in the village of Paluh Sibaji Pantai Labu Deli Serdang on reproductive health for pregnant women, such as parenting care for pregnancy, child birth and after child birth. Data was collected through in-depth interviews with a number of informants, consisting of pregnant women or those who had given birth, a number of community leaders, community members who were considered to know about the culture of the local community. The data was analyzed qualitative with the ethnography approach. You still has local knowledge of reproductive health for pregnant women, such as eating food like salted fish, squid, a number of fruits such as pineapple. Pregnant women may not leave the house in the afternoon before sunset due to the belief of a disturbing spirit. The purpose of abstinence is to avoid difficulties during childbirth and also for the safety of the baby to be born. Traditional birth attendants still play a large role as birth auqt tendants. Health workers also have a lot to help in the delivery process in the Paluh Sibaji Pantai Labu Deli Serdang.
\end{abstract}

Keywords: Knowledge system, pregnancy abstinence, reproductive health, ethnic Malay.

\section{Introduction}

Community life everywhere is never separated from culture, because culture exists because of its supportive community. Culture has elements, one of which is a knowledge system. One human effort to maintain and develop its culture is its ability to develop a knowledge system. Mitchell (2000) argues that local knowledge systems are rooted in local or traditional knowledge and management systems. Although in principle the objectives to be achieved are the same. Through the existing knowledge system, humans are able to adapt and adapt themselves to the surrounding environment. Every community has a system of knowledge about nature, about all the plants, animals, objects and people around them that come from their experiences, as well as the legacy of knowledge passed down from generation to generation. Thus each community has its own uniqueness that distinguishes its group from other community groups.

In achieving the prosperity of life, relativity people are loaded with a background of life and life views that are reflected in all the habits, values, traditions and customs of the community. The application and application of this view of life and life are realized in forms in the form of values, norms, ethics, beliefs, customary law, found in the habits of the 
community. One important aspect of culture is the practice of medicine which includes the practice of belief rituals. Every community must have a traditional knowledge system in maintaining reproductive health.

Cultural wealth from various ethnic groups scattered throughout Indonesia has colored various efforts in the health sector. Realized or not realized, trust factors and cultural conceptions including traditional knowledge underlie people's attitudes and behavior in relation to pregnancy care. These beliefs and cultural conceptions sometimes have a positive or negative impact on the health of pregnant women.

For example, ethnic Malays in Paluh Sibaji have a local knowledge system for reproductive health of pregnant women. It is realized or not realized, the trust factors and cultural conceptions including traditional knowledge underlie the attitudes and behavior of the community in relation to reproductive health. Therefore, research on the health culture of ethnic Malays in an effort to improve health status is very important The logical consequence must be realized that the diversity of cultures that exist in Indonesian territory, especially in . Paluh Sibaji requires careful understanding for each region with ethnicity in the region. Specific understanding of culture, by exploring local wisdom can be used as a specific locally specific health effort strategy. Malay ethnic culture that is characteristic of life patterns, and which has become a hereditary tradition, has great potential to influence health both from a negative and a positive side. Understanding community health status based on culture is one of the efforts to improve the health status itself, especially the health status of mothers and children. In some parts of the culture that exist in certain communities also known as abstinence foods that are food or dishes that should not be eaten because of cultural reasons, such as during pregnancy or breastfeeding, and because there is a certain belief in food in its culture.

Until now there were still many rediscovered what the ancestors could do centuries ago, the challenging custom was taught from generation to generation which tended to be adhered to even though the individuals who carried it out might not understand or that would be rational from reasons against food concerned, and just because of adherence to local traditions. But there are also some changes that are caused by reasons of challenging food that is no longer suitable for the development of the times.

Objectively, each particular group of people, especially in the Malay ethnic group in the Pantai Labu Deli Serdang have different health perceptions (healthy concept). This is very much determined by the culture of the community concerned. Every person who is disturbed by his health will find a way to heal himself from health problems or illnesses. It is increasingly recognized that culture cannot be ignored in influencing the health status of ethnic Malays. Likewise with Malays in Paluh Sibaji Pantai Labu, Deli Serdang they are still familiar with the knowledge system that is still adhered to and serves to maintain reproductive health for pregnant women. Maternal and child health problems are inseparable from sociocultural and environmental factors within Malay ethnicity wherever they are. Factors of trust and cultural knowledge such as conceptions of various taboos, causal relationships between food and healthy conditions of sickness, habits, and knowledge about health, can have a positive or negative impact on the health of the ethnic Malay community Paluh Sibaji Pantai Labu .

This is a potential and interest of the author to get information that needs to be explored in the ethnic Malay Paluh Sibaji Pantai Labu Deli Serdang From the background above, the writer raised the title "Ethnic Malay Knowledge System Against Reproductive Health of Pregnant Women in Paluh Sibaji Pantai Labu Deli Serdang ". 


\section{Methodology}

The location of this research is Paluh Sibaji Pantai Labu Deli Serdang. This location was chosen because of several villages located in Pantai Labu Deli Serdang Subdistrict, Paluh Sibaji Pantai Labu Deli Serdang which is still very thick with the ethnic Malay community's knowledge system on maternal reproductive health. Besides the chosen location is also a location that is found by many ethnic Malays, this location is also the location that is most easily taken by researchers.

The knowledge system of the ethnic Malay community at Paluh Sibaji Pantai Labu Deli Serdang towards the reproductive health of pregnant women in a study conducted with qualitative methods with an ethnographic approach. Therefore the methods commonly used are: participatory observation, in-depth interview, comparative, and holistic, the approach of the qualitative method of ethnographic approach taken is culture in depth description. To complete information or data obtained by the method through in-depth interviews. Data was collected through in-depth interviews with all informants consisting of pregnant women or mothers who had been pregnant and their families including their husbands and parents, village government officials, community leaders, health workers, traditional birth attendants and community members. Especially for pregnant women and mothers who have given birth. The selection of informants using snow ball technique starts with one of the people who can be used as the main source of information to provide recommendations to the villagers who can be used as the following informants who can provide more in-depth information about the object of research.

\section{Results and discussion}

Perceptions about pregnancy that are owned by the community differ and greatly determine people's behavior towards pregnancy. This perception of pregnancy is formed based on the beliefs and symbols that are owned by the community. Pregnancy experience in particular is a source of symbols about fertility, growth of babies in the womb, and maternal and child health. In the Malay ethnic community in the Paluh Sibaji Pantai Labu Deli Serdang , the type of food that was stabilized during pregnancy and after giving birth was quite a lot. Although not obeyed by all pregnant women, because they no longer feel strong traditional influences suppress the need for these restrictions to be obeyed. Interview results regarding knowledge of reproductive health of pregnant women: "If pregnant women here who do not abide by abstinence, children born are often affected by the disease, bunyu iitih / Lingko, black bunyu, their children are born black, their bodies are not big, their heads and stomach are large, there are also robusta diseases of children so skinny "(interview with Ms. Lina)

Similar to the results of interviews conducted with a community leader in the Paluh Sibaji Pantai Labu Deli Serdang, which stated that, prohibition against food, fruits, and behavior still exists today, and even if they are not adhered to have adverse effects on the health of the mother and child will be born:

"The belief in the knowledge of dietary restrictions and prohibitions on food, fruits and behavior, still exists today in this village, indeed this village is a village that is almost entirely ethnic Malays, a small part of other ethnic groups have also obeyed or followed restrictions on health. This pregnant mother, but even then it depends also on each person. If I myself really 
obey this kind of belief, because I feel it has a bad impact if it is not obeyed, I believe that if there are children who are born abnormally, it is because they do not obey abstinence and prohibition that has always been entrenched. when his wife is pregnant, her husband shoots a bird, then his child is born disabled. According to the knowledge and trustworthiness of the ancestors, that was why it was forbidden to kill animals when the wife was pregnant. So, boy, do I know about the culture of abstinence from pregnant women that I know of, so if you are obeyed better, because there is no harm, even if it is not obeyed then there are a lot of harm".

\subsection{Abstinence from food}

Problems that have a significant effect on pregnancy are nutritional problems. Nutritional problems in pregnant women in Indonesia cannot be separated from local cultural factors. This is because there are beliefs and restrictions on some foods. This is done because it is believed to get health for the mother and child to be born. Pregnant women believe that they should not eat salted fish which they think can increase blood pressure, as well as abstinence from eating feared squid which can cause the placenta or sticky placenta. Based on the results of the interview with a mother: "Pregnant people are forbidden from eating fish that have been dried because of pressure pain, there are also restrictions on eating squid because they stick to later, sometimes we want to eat it, but we think of a child in this stomach, so the birth will be healthy, so I myself when I was pregnant, all I thought about was, sometimes I also thought that if everything was backed up, my fear was that my child and I would be malnourished too, but I was more afraid of the risk of violating restrictions - this is the deck "( interview with pregnant women).

\subsection{Abstinence from behavior}

In addition to abstinence in certain forms of food, there are also a number of restrictions in the form of behavior. Abstinence from these behaviors is mainly related to the belief that maternal behavior during pregnancy will affect the safety and perfection of the baby being conceived. A pregnant woman should not wrap a towel around her neck because it will cause the baby to be born with the placenta wrapped around it, as revealed by one mother, There are a lot of prohibitions - actually the deck is broken, but that's how it is taught, it suddenly hurts to be obeyed, because this is the teaching that was passed down from ancestors from the past, and until now it has been used, which I know for example which is not allowed wrapped around a towel on the neck, then the child can wrap around the umbilical cord "(indepth interview with Miss Lina). Another abstinence is that pregnant women should not sleep using bolsters because it will cause the baby to be born with a big head, and should not sleep with a transverse position because it will cause the baby to be born breech. This was revealed through the statement of pregnant women supported by the opinions of community leaders.

"You can't use bolsters, your child will have the same head if you sleep, you can't breech with your husband and you are afraid that your child will be breech too" (in-depth interviews with community leaders). ) "there are restrictions, you can't sit near the door" (interview Miss Itet). There is also a ban on afternoon baths above five o'clock in the afternoon because it will cause the baby to be born suffering from influenza, as one mother revealed, "You can't take a shower late past 5 o'clock, later you can runny children when born" (DKT with pregnant women). 


\subsection{Prohibition of pregnant women husband}

Father also has prohibited abstinence that needs to be obeyed even though not as much as the ban on pregnant women. Father when returning home at night may not continue to enter the house, but need to pause outside the house. The goal is to confuse the ghost that follows. But in terms of rational thought, the aim is to defuse fathers who might be hot and to restore their original state as calm and patient. This is important if the wife is pregnant or has small children. Abdullah Yusof (2006: 131) also states that fathers to babies in the womb should not do "hard" work such as slaughtering chickens, killing animals, especially snakes, monkeys and dogs. This situation may result in the animal being exposed to his child and the child's dihuatiri who will be born with a split lips, numbness or disability. This abstinence does not educate the public so that they do not incite the animals because this act illustrates the cruel and cruel human attitude. Especially to a father who should be an example to children. According to Mbah Lina, one of the elders (the elder) in the study area, explained, that: "Babies who are still in their mother's womb can already hear what is said by their parents. Therefore women who are pregnant should not speak carelessly such as denouncing, or angry with others. The bad nature of a person who is denounced or scolded will decrease to the baby he is carrying. Likewise, someone who is a prospective father of a baby who will be born should also not denounce or scold other people, the event will be the same, the nature of the person being reproved or scolded will decrease in the baby. Maybe a husband whose wife is carrying an accident does something that violates these restrictions. For this reason, you should immediately say the baby's God forbid, if you do not immediately say the bad characteristics of the person who is reproached or scolded will decrease to the baby to be born. Health problems are complex problems that are influenced by various environmental, social, cultural, behavioral, genetic problems. Healthy terms contain a lot of cultural, social and medical understanding. In the past, from a medical point of view, health was closely related to illness and illness. In reality it is not that simple, health must be seen from various aspects. WHO looks healthy from various aspects. WHO defines a healthy notion as a perfect state of physical, spiritual, and social welfare. health experts, health anthropology is viewed as a biobudic discipline that pays attention to biological and socio-cultural aspects of human behavior, especially about the way of interaction between the two throughout the history of human life that affects health and disease. Disease itself is determined by culture: this is because disease is a social recognition that a person cannot carry out his normal role naturally. "Human ways of life and lifestyle are phenomena that can be associated with the emergence of various diseases, besides the results of various cultures can also cause disease People and traditional healers adhere to two causes of illness, namely: Naturalistic and Personalistic Naturalistic causes, namely someone suffering from illness due to environmental influences, food (wrong eating), life habits, imbalances in the body, including the belief of cold heat such as colds and congenital diseases.

\section{Conclusions}

Paluh Sibaji Pantai Labu Deli Serdang still believe in customs that challenge food and certain behaviors for pregnant and postpartum women. The cultural conception of abstinence is aimed at safeguarding the safety of mothers and babies, but the reasons given for symbolic restrictions. only health service providers and health workers need to understand the 
symbolic meaning contained in each abstinence so that they can make changes in the right way. It is better if it is supported by respect and openness with the traditional birth attendants to encourage the emergence of changes in childbirth assistance behavior in accordance with health principles. 


\section{References}

[1] Ahimsa-Putra, Heddy Shri.: Etnosains dan Etnometodologi: Sebuah Perbandingan. Masyarakat Indonesia, Tahun ke XII No. 2: 109-118, (1985)

[2] Daulay, Zainul.: Pengetahuan Tradisional : Konsep Dasar Hukum, Dan Praktiknya. Rajawali Press, Jakarta (2011)

[3] Foster dan Anderson.: Antropologi Kesehatan. Universitas IndonesiaPress, Jakarta (1986)

[4] Ihromi, TO.: Pokok Pokok Antropologi Budaya. Yayasan Obor Indonesia, Jakarta (2006)

[5] Humaedi, Alie.: Etnografi Pengobatan, Praktik Budaya Peramuan dan Sugesti Komunitas Adat Tau Taa Vana. PT. LKiS Pelangi Aksara, Yogyakarta (2016)

[6] Kusnadi.: Nelayan: Strategi Adaptasi dan Jaringan Sosial.: Humaniora, Bandun (2000)

[7] Moleong, Lexy.: Metode Penelitian Kualitatif. PT.Remaja, Bandung (2001)

[8] Muzaham, Fauzi.: Sosiologi Kesehatan. UI Press, Jakarta (1995)

[9] Muzaham, Fauzi.: Metodologi Penelitian Kualitatif. Pt.Remaja, Bandung : (2010)

[10] Poerwadarminta,dkk.: Kamus Lengkap Bahasa Indonesia. Pustaka, Jakarta (2012)

[11] Ritzer, George.: Teori Sosiologi Modern. Prenada Media Group, Jakarta (2011)

[12] Salim \& Syahrum.: Metodologi Penelitian Kualitatif. Citapustaka Media, Bandung (2012)

[13] Sibarani, Robert.: Kearifan Lokal: Hakikat , Peran, dan Metode Tradisi Lisan.Jakarta: Asosiasi Tradisi Lisan, (2012)

[14] Salim \& Syahrum.: Start programming using Object Pascal. Vol. 2, pp. 10-11. Legally Free Computer Books, US (2012)

[15] Subyantoro, A dan FX. Suwarto.: Metode dan Teknik Penelitian Sosial. Utama Press, Jakarta (2006)

[16] Simanjuntak, Bungaran-Antonius.: Melayu Pesisir dan Batak Pegunungan (Orientasi Nilai Budaya). Yayasan Obor Indonesia, Jakarta (2010)

[17] Spradley, James P.: Metode Etnografi (Terjemahan). Tiara Wacana, Yogyakarta (1997)

[18] Swasono, Meutia.: Kehamilan Kelahiran,Perawatan Ibu Dan Bayi Dalam Konteks Budaya. UI Press, Jakarta : (1998) 